\title{
Efektifitas Komunikasi Berkualitas untuk Meningkatkan Kehangatan dalam Pengasuhan Pada Orangtua Sibuk Bekerja Di KB-TK IT Al-Hikmah
}

\author{
Nangimatur Rofingah \\ Naimavicch319@gmail.com
}

\author{
Mohammad Mahpur
}

Fakultas Psikologi, Universitas Islam Negeri (UIN) Maulana Malik Ibrahim Malang, Indonesia

\begin{abstract}
Abstrak
Orangtua sibuk bekerja bukanlah penyebab dari keterlambatan dalam tumbuh kembang anak, akan tetapi kesibukan orangtua dalam bekerja menjadikan kurang terbentuknya kehangatan dalam pengasuhan yang menyebabkan tumbuh kembang anak tidak optimal. Salah satu faktor yang mempengaruhi tingkat kehangatan dalam pengasuhan adalah komunikasi yang terjalin antara anak dengan orang tua yang terbatas. Hal ini dapat dilihat dari waktu kebersamaan orang tua yang sibuk bekerja dengan anak sangat minim. Untuk itulah perlu adanya komunikasi yang berkualitas secara waktu agar kehangatan dalam pengasuhan dapat diterima oleh anak. Minimnya waktu yang dimiliki oleh orangtua sibuk bekerja yang diberikan pada anak menjadi sebuah problematika penting yang harus segera diselesaikan. Melalui metode action research dengan pengolahan data secara deskripif disertai dengan kuantitatif sebagai pelengkap, penelitian ini bertujuan untuk mengetahui keefektifan komunikasi berkualitas dalam meningkatkan kehangatan dalam pengasuhan pada orangtua sibuk kerja. Subyek dalam penelitian ini adalah 5 orangtua sibuk kerja di KB/TK-IT Al-Hikmah Blitar. Penelitian ini dilakukan selama kurang lebih 2 bulan. Setelah diterapkannya komunikasi berkualitas ternyata mampu meningkatkan kehangatan dalam pengasuhan orangtua sibuk kerja ditandai dengan meningkatnya indikator penghargaan, dukungan dan responsifitas orangtua dari $26 \%$ meningkat menjadi 38\%. Kesimpulannya bahwa penelitian ini selain dapat membuktikan bahwa komunikasi berkualitas mampu digunakan untuk meningkatkan kehangatan pengasuhan juga dapat diterapkan pada bidang pendidikan terutama dalam hal pengasuhan anak, penelitian ini mengkombinasikan antara pihak sekolah dengan keluarga sehingga perkembangan anak berjalan dengan seimbang.
\end{abstract}

Kata kunci : kehangatan Pengasuhan, komunikasi berkualitas, Orangtua Sibuk Kerja

Psikoislamika : Jurnal Psikologi dan Psikologi Islam (JPPI) Volume 15. Nomor 2, Tahun 2018. copyright (C) 2018. Pusat Penelitian dan Layanan Psikologi.

\section{PENDAHULUAN}

Kehangatan merupakan perilaku orangtua yang ditunjukkan dengan penghargaan, dukungan, dorongan serta responsivitas pada anak dan kebutuhannya. Anak yang mendapatkan kehangatan yang tinggi dalam pengasuhan akan cenderung aman dengan orangtuanya karena kehangatan merupakan salah satu perilaku pengasuhan yang responsif dan sensitif. Kehangatan dapat diekspresikan dengan kasih sayang orangtua pada anak melalui ciuman, rangkulan bahkan pelukan hangat (Dimas, 2006).
Kurangnya kehangatan dalam pengasuhan menjadi penyebab anak kurang optimal dalam masa perkembangannya. Menurut Chen dalam Lestari (2012) menyatakan bahwa kehangatan merupakan komponen mendasar dalam hubungan orangtua dengan anak, anak akan merasa terpenuhi kasih sayang dan rasa percaya dirinya lebih berkembang. Kehangatan memberikan efek positif yang meningkatkan mood agar sikap kepedulian lebih tercipta dan lebih empati satu sama lain. Zaman sekarang orangtua merasa kesulitan untuk mengungkapkan cintanya, orangtua merasa malu atau bahkan tidak sempat untuk melakukannya pada anak padahal 
ungkapan kasih sayang yang diekspresikan merupakan bentuk dari kehangatan pengasuhan yang melahirkan rasa aman dan nyaman pada anak. Dengan kehangatan pengasuhan inilah anak akan merasa dihargai, diterima dan merasa dicintai apa adanya oleh orangtua.

Rahayu (2009) suasana yang penuh kasih sayang, kehangatan dan menerima anak sebagaimana adanya akan memberikan rangsangan dalam segala aspek perkembangan anak baik secara kognitif, afektif dan psikomotor, dan semua itu merupakan jawaban bagi tumbuhnya generasi yang unggul di masa depan. Faktor terpenting yang menyumbang keberhasilan adalah keterlibatan yang positif orangtua dalam pendidikan dan pembelajaran anaknya.

Investigasi yang dilakukan oleh Hess (dalam Santrock, 1995) menunjukkan bahwa perilaku yang diterapkan ibu sehingga menghasilkan anak yang memiliki kompetensi di kelas adalah program komunikasi efektif dengan anak, relasi yang hangat dengan anak, harapan positif untuk berprestasi, penerapan disiplin yang berdasarkan pelatihan dan bukan disiplin yang berdasarkan kekuasaan. Namun jika pengasuhan yang diberikan tidak tepat berakibat meningkatkan resiko permasalahan baik itu perilaku maupun emosional pada anak. Anak menjadi menarik diri, mudah menjadi korban kekerasan seksual (UUSDHHS, dalam Papalia dkk, 2002), anak bisa memiliki hubungan sosial dan harga diri yang rendah, akibat buruknya mengalami hambatan belajar atau tinggal kelas, mengalami kesulitan untuk mengelola emosi dan berpotensi mengalami gangguan psikologis ketika dewasa bahkan menurut Grossman dan Rowat (2004) orangtua ketika tidak menyayangi anaknya akan lebih berdampak negatif dibandingkan orangtua yang berkonflik atau bercerai. Penelitian yang dilakukan peneliti pada orangtua yang menyekolahkan anaknya di KB/TK IT AlHikmah melalui wawancara pada bulan agustus 2017 di Blitar untuk mengetahui permasalahan perkembangan anak yang terlambat di rumah, Sebagian besar ibu mengatakan masih merasa kesulitan ketika anaknya sulit diatur, sering berebut mainan dengan temannya, marah-marah sampai menangis ketika keinginannya tidak dipenuhi, terkadang terlalu banyak bermain dan susah ketika di ajak tidur maupun mandi. kebanyakan, ibu-ibu menggunakan cara-cara yang biasa dilakukan oleh pengalaman yang telah didapatnya yaitu menasehatinya, berkata anak yang bandel (melebel), bahkan membentak dan mengancam dengan menjewer, mencubit, bahkan terkadang juga diberi hukuman.

Berdasarkan hasil wawancara, orangtua tua kurang konsisten dalam menerapkan kedisiplinan pada anaknya. Menurut aspek kehangatan dibutuhkan responsif yang lebih dalam pengasuhan namun masih banyak orangtua yang salah dalam merespon perilaku bermasalah yang dilakukan oleh anaknya. Anak di usia dini harus mendapatkan perhatian yang penuh dan serius dari orangtuanya (Fitriah \& Nordin, 2014: 17). Namun, karena kesibukan bekerja, orangtua sering tidak melanjutkan pembiasaanpembiasaan baik yang telah di dapatkan anak dari sekolah. Sehingga program parenting yang telah berjalan disekolah tidak berjalan dengan maksimal dan selaras.

Bagi orangtua yang sibuk bekerja sering terjadi kesalahpahaman dalam mengartikan waktu berkualitas. Wesserman dan Darwis (dalam Rahmat, 2005) mengatakan bahwa kurangnya komunikasi akan menjadi penghambat perkembangan kepribadian (personal patology). Komunikasi merupakan faktor penting untuk perkembangan karena komunikasi memiliki fungsi memberbaiki hubungan anak dengan orangtuanya, sehingga diharapkan dapat mempermudah internalisasi nilai-nilai orangtua pada anaknya.

Komunikasi dikatakan berhasil bukan sekedar pandai dalam berbicara atau membahasakan tubuhnya namun komunikasi itu bersifat efektif dan berkualitas. Yang menjadi permasalahan adalah bukanlah berapa kali komunikasi itu dilakukan namun bagaimana komunikasi itu dilakukan (Rahmat, 2005). Panji $\mathrm{H}$ (2014) Mengatakan dengan komunikasi berkualitas anak lebih mampu dalam memilih pergaulan sehingga hubungan antara orangtua dengan anak tetap berjalan dengan baik dan normal.

\section{Pengasuhan}

Pengasuhan yang pertama kali diterima oleh anak berasal dari keluarga, keluarga memiliki peranan yang sangat penting dalam mengembangkan pribadi anak. Kartono (1997 : 250) juga menyebutkan bahwa keluarga merupakan lembaga pertama untuk anak dalam sosialisasi. Dari keluarga inilah anak belajar mengenal makna cinta kasih, simpati, loyalitas, idiologi, bimbingan dan pendidikan. 
Saat proses mengasuh anak, orangtua juga berperan dan bertanggungjawab untuk tercapainya kesejahteraan (well-being) anak, mewujudkan independensi anak dan menjembatani proses internalisasi nilai-nilai sehingga anak berkembang dalam budaya asuh yang positif. Hubungan tersebut adalah sebuah cara orangtua menunjukkan rasa cinta dalam mengasuh anak, wujud adanya kepedulian dan perlindungan sehingga anak bertumbuh dan berkembang dengan pengalaman hidup positif (Zlotnick, Wright, Sanchez, Kusnir, \& Te'oBennett, 2010).

Baumrind (2008) telah mengemukakan dua faktor pengasuhan yang diterapkan orangtua, yaitu responsiveness dan demandingness.

Bogenscneider dan Pallock (2008) yang beranggapan bahwa respomsiveness merupakan komponen dasar dalam kapasitas pengasuhan untuk anak. Hal tersebut berupa perhatian terhadap kebutuhan anak dan adanya kehangatan dalam keluarga. Responsiveness diukur melalui penerimaan kedekatan, kualitas hubungan dan kehangatan orangtua dengan anak. Sedangkan demandingness mengacu pada ketegasan dalam aturan dan standart perilaku yang di inginkan.

Pembentukan perilaku dan sikap anak akan efektif apabila hubungan antara anak dan juga orangtua dilakukan dengan penuh cinta dan rasa aman, Sisca (dalam Hurlock, 1990) menerangkan apa yang dipelajari anak tergantung pada bagaimana orangtua memenuhi kebutuhan anak akan perhatian, makanan dan cinta kasih.

\section{Kehangatan}

Menurut Potter \& Perry (2009) menjelaskan bahwa kehangatan merupakan bagian dari fasilitas komunikasi yang seperti rasa hormat, empati dan juga kesejatian atau keikhlasan. Kehangatan pengasuhan merupakan aspek tertinggi dalam memberikan jalan pengasuhan yang aman bagi anak (Barbara, 2004:42). Tidak cukup apabila hanya mencintai anak dari hati saja, anak-ank membutuhkan cinta yang ditunjukkan dalam aksi nyata, misalkan ciuman, pelukan, dan tatapan yang menyenangkan, dengan hal tersebut anak akan merasakan kehangatan dari orangtuanya (Ibrahim, 2006:138).

Menurut Rita (2007) ada 3 aspek kehangatan dalam pengasuhan. Penghargaan. Adanya perilaku orangtua yang memuji, mendorong, sentuhan kasih sayang fisik, ketersediaan fisik dan psikologis dan menerima kemampuan (tidak mengkritik). Dukungan. Dukungan yang ditunjukkan dengan keterlibatan dalam interaksi positif, memberikan persetujuan dengan apa yang dilakukan anak. Menurut Sarafino (dalam Dowle, 2006) menyebutkan bahwa ada lima macam dukungan, diantaranya: dukungan emosional, esteem, instrumental, informassional dan jaringan. Responsif. Responsif merupakan sikap yang ditunjukkan orangtua pada anak secara cepat terhadap isyarat dan kebutuhan anak.

Namun pada era perkembangan zaman pengasuhan anak mulai terabaikan terhitung dari banyaknya wanita yang bekerja dengan berbagai alasan yang dimiliki selain supaya mandiri secara ekonomi juga sebagai tambahan penghasilan keluarga, dan mengisi waktu dengan mengembangkan prestasi dan potensi yang dimilikinya (Niken \& Theresia, 2004). Ada sisi positif bagi anak yang ditinggal oleh kedua orangtuanya untuk bekerja, anak akan menjadi lebih cepat mandiri karena tidak terus-menerus dibantu. Anak terbiasa memenui kebutuhan dan belajar sendiri, namun dampak negatif lebih dirasakan bagi anak yang ditinggal kedua orangtuanya bekerja. Desi (2009) menyatakan bahwa sisi lain kalau anak dibiarkan terus menerus sendirian, ada dampak kehilangan yang bisa terjadi, yang paling mungkin adalah kehilangan teman berbincang-bincang (berkomunikasi) serta tidak ada respon dari orang yang lebih dewasa terhadap perilakunya.

Peran aktif orangtua terhadap perkembangan anaknya sangat diperlukan terutama disaat mereka berusia dibawah lima tahun, Ayu T (2012 :84) mengatakan bahwa kurangnya peran ibu dalam pemenuhan kebutuhan dasar anak tentunya memiliki dampak yang kurang baik bagi perkembangan anak. Tidak hanya ibu saja namun dampak dari orangtua yang keduanya bekerja tidak hanya mempengaruhi fungsi kognitif, melainkan juga mempengaruhi mental, emosional, sosial, kemandirian anak, status kesehatan dan status gizi (Dinkes Riau, 2014).

Menurut Li, et al, (2013) waktu bekerja menyebabkan gejala depresi pada orangtua, penurunan kualitas pengasuhan dan interaksi serta kedekatan antara orangtua dan anak. Fenomena orangtua yang sibuk bekerja dan penyimpangan tumbuh kembang anak perlu adanya identifikasi yang lebih mendalam. Hal tersebut merupakan masalah yang sedang dihadapi oleh keluarga sekarang ini, karena kesibukan bekerja menjadikan perhatian orangtua kepada anaknya menjadi berkurang sehingga 
waktu orangtua semakin sedikit untuk mendidik anaknya yang akibatnya komunikasi antara orangtua dengan anak juga berkurang.

Kesimpulan dari seluruh kajian, kemudian memberikan gambaran operasional mengenai kehangatan pengasuhan anak pada orang tua sibuk bekerja. Bahwa kehangatan pengasuhan harus tetap ditumbuhkan pada orangtua sibuk kerja. Dengan kehangatan pengasuhan tersebut anak dapat tetap tumbuh dan berkembang dengan baik, namun jika anak tidak menerima kehangatan pengasuhan dari orangtuanya akan memberikan resiko-resiko yang dapat merugikan baik itu pada anak maupun pada orangtua. Sehingga perlu adanya perbaikan komunikasi sebagai langkah awal memperbaiki pengasuhan yang ideal.

\section{Komunikasi}

Komunikasi diperlukan didalam sebuah keluarga sebagai aspek yang dapat membentuk keluarga yang harmonis, dalam mencapai keluarga yang harmonis tanpa komunikasi kerawanan pecahnya hubungan antara orangtua dengan anak akan sulit untuk dihindari. Robitoh (dalam Syaiful B : 2004) menyatakan bahwa dalam mendidik anak yang cerdas tidak dapat terlepas dari pemanfaat komunikasi dalam islam seperti qaulan karima, qaulan sadida, qaulan ma'rufa, qaulan baliga, qaulan layyina, dan qaulan maisura ketika orangtua berkomunikasi dengan anak, komunikasi dapat membentuk anak yang cerdas secara intelektual, emosional dan spiritual. Komunikasi yang berhasil bukan hanya sekedar kepandaian berbicara, melainkan komunikasi itu sendiri bersifat efektif atau berkualitas yang menjadi soal bukanlah berapa kali komunikasi dilakukan, tetapi bagaimana komunikasi itu dilakukan (Rakhmat, 2005).

Menurut Laswell (1987) terdapat aspek-aspek dalam kualitas komunikasi yang akan menjadi komunikasi berkualitas. Keterbukaan. Sejauh mana orangtua dapat terbuka dengan anak sehingga anak mampu menemukan kenyamanan dengan pengasuhannya. Kejujuran. Komunikasi yang jujur perlu ditanamkan sejak dini oleh orangtua, karena hal inilah yang akan membentengi anak dalam melakukan sikap-sikap terpuji (honorable, creditable, respectable) (Dinar, 2017). Kepercayaan. Dengan percaya anak akan menjalin hubungan yang lebih akrab dan berlangsung secara mendalam. Secara ilmiah percaya berarti mengandalkan perilaku orang untuk mencapai tujuan yang dikehendaki (Rakhmat, 2005). Empati. Komunikasi yang empati bisa dilakukan dengan memotivasi, kontak mata, tidak memotong pembicaraan, menunjukan minat berkomunikasi dengan anak dan bersikap wajar dengan anak, dengan empati ini pesan yang ingin disampaikan oleh orangtua akan lebih dapat dipahami dan diterima oleh anak (Indriani, 2014). Mendengarkan. Mendengarkan merupakan aktivtas tanpa biaya, tetapi aktivitas yang sangat berharga yang tidak boleh disalah artikan (C Drew, 2006:93). Orangtua juga perlu untuk menerapkan sikap sabar dalam berkomunikasi dengan anak.

Agar orangtua dapat melakukan komunikasi dengan terbuka, jujur, percaya, empati dan mendengarkan orangtua dapat melakukan komunikasinya dengan membuat karakteristik waktu yang juga berkualitas (quality time), orangtua dapat mendukung anak-anak mereka melalui kegiatan keluarga seperti makan bersama, jalan-jalan, nonton film, atau pergi berlibur bersama. Astati (2012) mengartikan waktu berkualitas adalah adanya kualitas waktu yang berhubungan dengan kondisi di mana setiap anggota keluarga menekankan arti pentingnya kebersamaan dan kebermaknaan dalam suasana keluarga. Yang pada akhirnya anak mengharapkan adanya keharmonisan dan fleksibel hidup antara ayah dan ibu, ibu dan anak, dan begitu sebaliknya.

Waktu untuk bertatap muka sangatlah penting untuk membangun hubungan yang lekat, dekat dan hangat dengan seorang anak. Bukan kuantitas waktu yang kita habiskan bersama anak-anak akan tetapi kualitaslah yang paling penting, meskipun keduanya sama-sama dibutuhkan anak. Kurangnya bertatap muka dengan anak yang positif selain memiliki dampak yang negatif juga menciptakan konsekuensi yang tidak menyenangkan. Kuantitas dan kualitas waktu yang dihabiskan orangtua dengan anak ketika anak masih kecil akan memberikan damapak hubungan ketika dewasa nanti (C Drew, 2006:101).

Berdasarkan fenomena yang ada peneliti mencoba untuk membuktikan efektifitas komunikasi berkualitas yang telah orangtua terapkan melalui design modul yang telah peneliti rancang dalam sebuah buku pendampingan (guide book) dalam meningkatkan kehangatan pengasuhan, sehingga penelitian ini diharapkan mampu menjawab bagaimana langkah orangtua yang sibuk bekerja namun tetap menjalankan tanggung jawabnya sebagai orangtua. 


\section{METODE}

Metode yang digunakan dalam penelitian ini adalah penelitian tindakan (action research). Hart dan Bond (1995) melihat bahwa action research adalah penelitian berbasis edukatif, menyepakatkan antar individu sebagai anggota suatu kelompok. Action research lebih jauh adalah focused yang melibatkan suatu intervensi perubahan yang bertujuan mengembangkan dengan melibatkan ada suatu lingkaran proses yang bisa diperoleh melalui kolaborasi. Dalam penelitian ini menggunakan model penelitian tindakan dari Stepen Kemmis yang mengembangkan model sederhana, perputaran alami dari proses action research. Tiap perputaran terdiri dari empat langkah, diantaranya : perencanaan, tindakan, evaluasi dan refleksi.

Daftar masalah dari hasil observasi adalah program parenting yang telah ada disekolah belum berjalan dengan lancar karena kesibukan orangtua dalam bekerja, kesibukan orangtua membuat waktu yang seharusnya digunakan untuk bersama anak menjadi terbagi dengan waktu kesibukan orangtua. Sehingga peneliti membuat rancangan tindakan sebagai solusi agar orangtua tetap dapat memberikan pengasuhan yang optimal disamping kesibukan bekerja. Ada 3 tindakan dalam penelitian ini yaitu melihat tingkat kehangatan dan mengkategorikannya kemudian memberikan perlakuan quality time dan komunikasi bekualitas yang telah dirancang dalam guide book. Perlakuan ini diberikan agar orangtua dapat membagi waktunya diantara ketiga zona yang kemudian dapat melakukan perilaku komunikasi berkulitas di masing-masing zona. Setelah dilakukan tindakan peneliti juga melakukan evaluasi dan refleksi ketika perlakuan yang diberikan kurang memberikan efek pada subyek penelitian.

Dalam penelitian ini peneliti menggunakan purposive sampling (penentuan sampel dengan pertimbangan tertentu), yaitu 5 orangtua sibuk kerja. Waktu penelitian ini kurang lebih 2 bulan melalui kerjasama yang dilakukan dengan KB/TK-IT Al-Hikmah Blitar, mulai bulan februari hingga april. Teknik pengumpulan data dilakukan melalui. Observasi, wawancara mendalam, pretest, pemberian perlakuan dengan guide book, evaluasi dan posttest.

Instrumen yang digunakan adalah modifikasi skala kehangatan pengasuhan dari 3 indikator menjadi 10 item yang memiliki jenjang respon 1-
4. Aspek komunikasi berkualitas dimodifikasi menjadi bahan perlakuan untuk meningkatkan kehangatan yang telah dirancang di dalam guide book. Analisis data dilakukan dengan dua cara yaitu analisis deskriptif dan uji tanda Wilcoxon Signed Rank Test.

\section{HASIL DAN PEMBAHASAN}

Berdasarkan hasil deskripsi data dapat dikategorisasikan orangtua dalam kategori sedang dan tinggi, subyek dalam kategori sedang sebanyak 3 dan kategori tinggi sejumlah 2 subyek. 3 subyek dalam kategori sedang memiliki kesempatan untuk meningkatkan kehangatan dalam pengasuhan hingga mencapai kehangatan pengasuhan dalam kategori tinggi. Sedangkan 2 subyek dalam kategori tinggi yang telah memiliki kategori ideal dalam kehangatan pengasuhan juga masih memiliki kesempatan untuk mempertahankan ataupun lebih meningkatkan kembali sampai pada skor maksimal.

Uji normalitas dilakukan untuk melihat skor variabel. Hasil data menunjukkan bahwa data berdistribusi normal karena memiliki nilai $\mathrm{p}>$ 0.05. namun subyek dalam penelitian ini berjumlah < 30 sehingga peneliti menggunakan wilcoxon signed rank tes.

Hasil uji wilcoxon Signed Rank Test

\begin{tabular}{|c|c|c|c|}
\hline \multicolumn{4}{|l|}{ Test Statistics ${ }^{a}$} \\
\hline & $\begin{array}{l}\text { posttest } 1 \\
- \text { pretest }\end{array}$ & $\begin{array}{l}\text { posttes2 - } \\
\text { posttest1 }\end{array}$ & $\begin{array}{l}\text { posttes } 2 \\
\text { - pretest }\end{array}$ \\
\hline $\mathrm{Z}$ & $-2,032^{\mathrm{b}}$ & $-2,041^{\mathrm{b}}$ & $-2,023^{b}$ \\
\hline $\begin{array}{ll}\begin{array}{l}\text { Asymp. } \\
\text { (2-tailed) }\end{array} & \text { Sig. } \\
\end{array}$ &, 042 & ,041 &, 043 \\
\hline \multicolumn{4}{|c|}{ a. Wilcoxon Signed Ranks Test } \\
\hline \multicolumn{4}{|c|}{ b. Based on negative ranks. } \\
\hline
\end{tabular}

Untuk $\mathrm{n}$ (jumlah data) $=5$, tingkat signifikasinya adalah $0,043<0.05$, maka $\mathrm{H} 0$ ditolak, yang bermakna komunikasi berkualitas mempunyai efek dalam meningkatkan kehangatan pengasuhan. Hasil dari pretest sampai ke posttest kedua masing-masing subyek memiliki variasi peningkatan, selisih menunjukkan adanya peningkatan, namun ada 1 subyek yang tidak mengalami peningkatan pada postest kedua.

Hasil tingkat kehangatan pretest dan posttest 
Tingkat Kehangatan

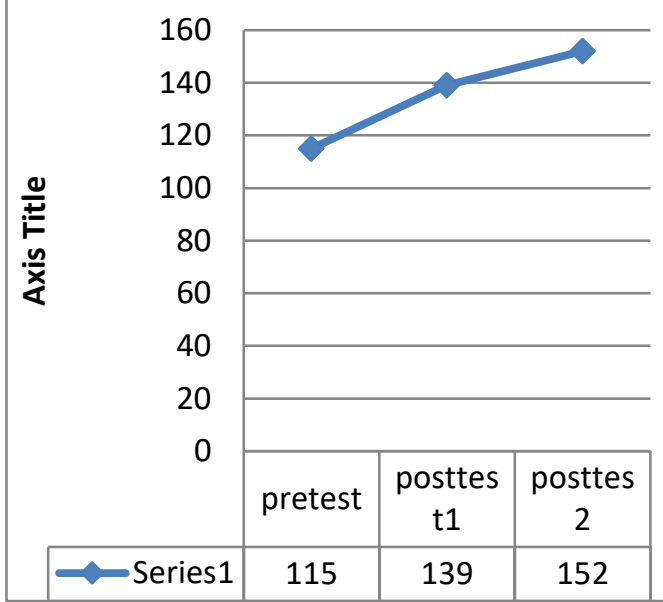

Hasilnya dapat dilihat pada tabel di atas. Berdasarkan hitungan selisih (Gain Score) dapat disimpulkan bahwa komunikasi berkualitas dapat mempengaruhi dalam meningkatkan kehangatan pengasuhan pada subyek. Analisis Deskriptif

Analisis Deskriptif ini dilakukan bertujuan untuk mengetahui lebih dalam mengenai perubahan yang telah dialami oleh subyek. Dari pretest ke posttest pertama selisih skor peningkatannya ada 24 , peningkatan ini terjadi pada indikator dukungan dan

indikator responsif, sedangkan pada indikator penghargaan tidak mengalami peningkatan. karena pada posttest pertama peneliti berasumsi hasil perubahan kurang memenuhi keberhasilan yang diinginkan sehingga dilakukan posttest kedua. Dari posttest kedua ini diperoleh selisih peningkatan sejumlah 13 poin sehingga total selisih peningkatan adalah 37 poin. Pada postest kedua ketiga indikator mengalami peningkatan, indikator penghargaan menunjukkan selisih yang paling tinggi diantara indikator dukungan dan responsif.

Kemampuan Memberikan Kehangatan dalam Pengasuhan. Setelah diberikan perlakuan komunikasi berkualitas 3 subyek berada pada kategori sedang dan 3 subyek berada pada kategori tinggi.

Kemampuan Memetakan Waktu yang Berkualitas. Orangtua mampu memberikan warna merah, kuning, dan hijau pada setiap zonanya sehingga dari pemetaan waktu yang telah dilakukan, orangtua dapat melakukan komunikasi berkualitas pada setiap zonanya.
Pemetaan Waktu Orangtua Sibuk Kerja

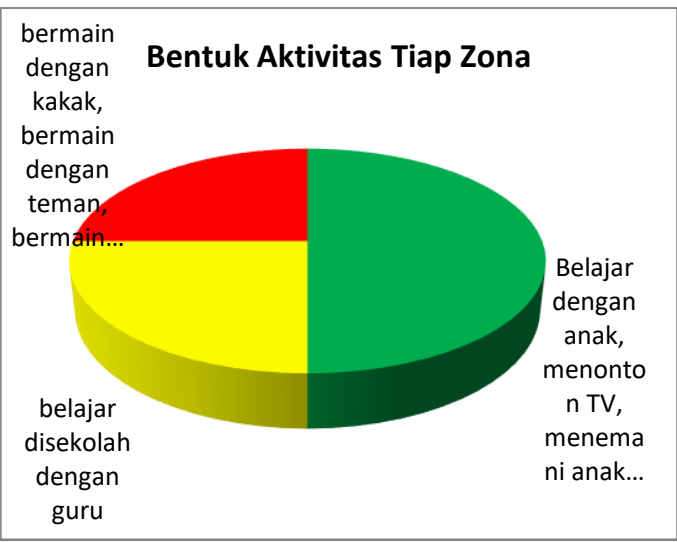

waktu Gold yang dimiliki oleh orangtua untuk anaknya adalah diwaktu sore hingga malam hari. dan waktu siang hingga sore merupakan waktu yang rentan bagi anak karena jauh dari pantauan orangtua. Sedangkan waktu tengah adalah zona kuning dimana sekolah telah memberikan pengajaran yang baik, dan bagaimana orangtua tetap dapat menyeimbangkan pendidikan yang telah anak dapat disekolah.

Kemampuan Menerapkan Komunikasi Berkualitas dengan Perilaku. subyek mampu menentukan sendiri komunikasi yang tepat pada masing-masing zona, dari kemampuan memilih dan melaksanakan komunikasi berkualitas ini sehingga didapat subyek mampu meningkatkan kehangatan dalam pengasuhannya. Dari perlakuan yang diberikan subyek mampu memahami bagaimana orangtua memberikan penghargaan, dukungan dan sikap yang responsif pada anak. subyek sering melakukan komunikasi berkualitas sehingga didapat semakin baik kehangatan yang diberikan pada pengasuhannnya.

Secara spesifik Indikator kehangatan. Semua indikator mengalami peningkatan. indikator penghargaan kurang mengalami skor peningkatan, hal ini dikarenakan sebagian besar subyek dalam perlakuannya terfokus pada indikator dukungan dan responsifitas orangtua pada anak.

Selisih per Indikator kehangatan 


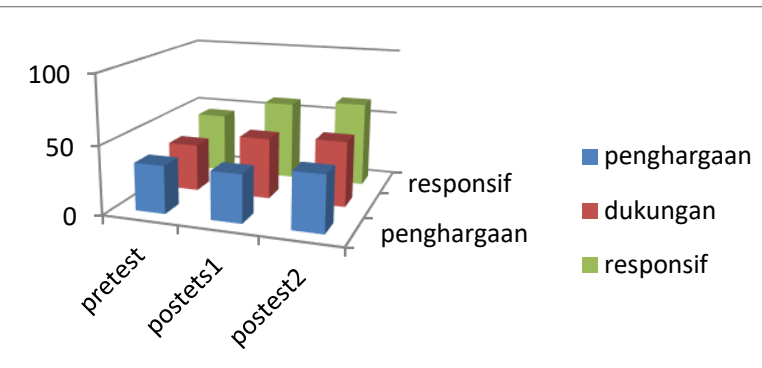

Indikator Penghargaan. telah ditunjukkan dengan sikap subyek (orangtua) dalam sikap mulai seringnya untuk memberikan ucapan bangga pada anak, sering memuji ketika anak dapat melakukan hal yang sulit dan ketika anak dapat menyelesaikan pekerjaannya sendiri dengan baik. MA semakin sering memanggil SAYANG pada anaknya, subyek MS dan MB mulai untuk sering memuji kehebatan kecil yang dilakukan oleh anak.

Indikator Dukungan. dapat dilihat dari sikap subyek dalam berperan aktiv di sekolah, subyek mulai untuk sering bertanya pada pihak sekolah mengenai perkembangan anak atau hal apa yang dilakukan oleh anak disekolah, Subyek MA menjadi sering memberikan semangat dan kalimat-kalimat yang menyenangkan pada anak. Subyek MS memberikan pengertian yang lebih pada anak ketika ditinggal bekerja, subyek MK dan MV mengajak anak dalam hal belajar.

Indikator Responsif. Pada indikator ini dapat dilihat tentang kepekaan orangtua dalam membaca kondisi dan situasi yang dibutuhkan oleh anak, orangtua mulai memberikan perhatian yang lebih pada anak mereka disamping mereka harus bekerja. Subyek MB mulai aktiv bertanya pada anak mengenai hal yang dilakukannya, Subyek MK semakin sering bertanya mengenai perkembangan anak pada guru, subyek MV lebih sering mendiskusikan dengan anak mengenai kegiatan yang dilakukan.

Hasil penelitian ini menunjukkaan bahwa komunikasi sangat efektif dilakukan untuk meningkatkan pengasuhan yang positif, Dari kondisi orang tua yang belum mengetahui cara mengasuh anak dan menjalin kedekatan dengan anak, dapat dilakukan dengan komunikasi yang semakin sering dan berkualitas, tentunya dengan waktu yang telah terbagi dengan baik. Orangtua juga perlu untuk mengetahui keadaan anak melalui unsur sekolah, inilah yang akan membantu orangtua dalam menuntaskan perkembangan anaknya, hal ini juga disampaikan oleh Mariana (2010). Dari kelima subyek 1 subyek yang telah menerapkan komunikasi berkualitas secara maksimal, karena kesiapan orangtua yang matang dalam memberikan pengasuhan pada anak. namun keempat subyek yang lain juga telah berusaha untuk memberikan pengasuhan yang baik pada anak-anaknya, terutama dalam memberikan kehangatan.

\section{PEMBAHASAN}

Dari hasil pretest menunjukkan skor yang belum maksimal, rata-rata orangtua memiliki skor sedang dan rendah. Ini terjadi karena orangtua belum mengetahui cara memetakan waktu kesibukan kerja dengan waku untuk anak. karena kesibukan orangtua sehingga orangtua mempercayakan sepenuhnya pada pihak sekolah. Namun karena tidak seimbangnya pengasuhan yang diberikan pada anak antara disekolah dan rumah sehingga menyebabkan tumbuh kembang anak menjadi kurang optimal.

Secara umum MA, MS, MB, MK dan MV telah mampu memberikan kehangatan dalam pengasuhan, melalui komunikasi berkualitas yang dibangun dan diterapkan setiap harinya oleh orangtua pada anak. Anna (2015) menyatakan bahwa penghargaan dari orangtua akan mampu membantu anak dalam meningkatkan prestasinya, sesuai dengan hasil peningkatan indikator penghargaan orangtua telah memberikan penghargaan yang lebih pada anak, sehingga anak mendapat kondisi psikologis yaitu merasakan kenyamanan dengan orangtuanya, dengan rasa nyaman tersebut didapatkan kondisi perilaku anak tidak mudah rewel, tidak mudah putus asa dan anak mampu melakukan pekerjaannya dengan mudah. Orangtua telah melakukannya dengan tersenyum ketika memberikan nasehat pada anak ataupun memuji

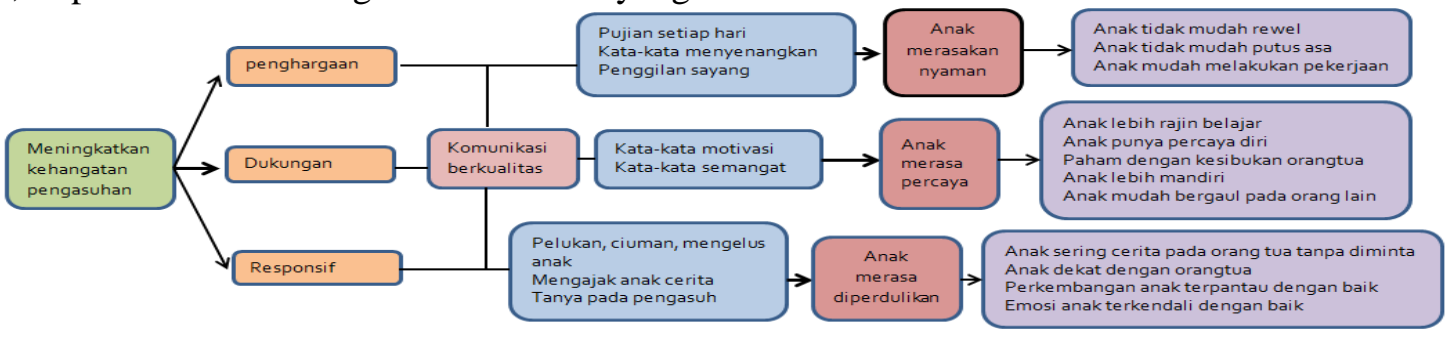


anak dengan kata-kata yang menyenangkan, misalkan memuji anak hebat dan anak cerdas dan panggilan sayang sehingga anak akan merasa medapat penghargaan yang lebih dari orangtuanya. Pengasuhan yang baik dan positif akan membantu perkembangan sosial emosional anak (Fitriah \& Nordin, 2014).

Dari peningkatan indikator dukungan, orangtua melatih untuk memberikan kata-kata semangat dan motivasi setiap anak akan berangkat kesekolah atau kegiatan yang lain, ketika anak mendapatkan dukungan penuh dari orangtuanya, memunculkan kondisi psikologis yaitu menumbuhkan rasa percaya antara anak pada orangtuanya sehingga dari rasa kepercayaan yang dimiliki anak inilah muncul perilaku anak menjadi lebih mudah dalam bergaul dengan teman-temannya, anak juga menjadi lebih rajin dalam belajar.

Dari sikap responsif yang diterapkan, melatih kepedulian orangtua pada anak, melalui sikap responsif orangtua menjadi memiliki kepekaan yang lebih tinggi. dengan sering mengajak anak untuk bercerita, memberikan respon yang baik ketika anak sedang bersama, dan berinteraksi dengan orang-orang yang dekat dengan anak saat orangtua tidak bersama dengan anak (tanya pada pengasuh), membuat anak menjadi lebih dekat dengan orangtua meskipun dengan waktu yang terbatas. subyek telah mampu meningkatkan ketiga indikator dengan komunikasi berkualitas yang telah diterapkan, peningkatan terjadi secara kontinyu (terlihat pada grafik 4.8 peningkatan per indikator) meski tidak setiap aspek memiliki peningkatan yang sama rata. Artinya, penelitian ini menunjukkan ketika orangtua sibuk kerja mampu menjalin komunikasi yang baik maka kehangatan dalam bentuk penghargaan, dukungan dan sikap responsif yang seimbang akan memberikan kualitas pengasuhan yang baik. Keberadaan orangtua memiliki pengaruh besar pada perkembangan anak. menurut Sekumune (dalam Harmaini, 2013) dalam penelitiannya menyatakan bahwa orangtua yang sering jauh dari anak kurang memberikan perhatian pada anak-anaknya. kasus yang ditemukan peneliti bahwa ketika anak sering berada jauh dari orangtuanya, anak menunjukkan kecemasan yang lebih tinggi dibandingkan anak yang dekat dengan orangtuanya. Kedekatan pada keluarga yang hangat dan lebih terbuka dalam kebersamaan dapat merangsang anak mengeluarkan kata-kata, berani bertanya, banyak bercerita pada orangtua dan mengekspresikan diri secara aktiv.
Suhendi \& wahyu (2001) menyatakan bahwa kemampuan orangtua yang konsisten, tegas dan mampu bekerja sama dapat menjadikan teladan yang baik bagi kehidupan anak-anaknya. Penelitian yang telah dilakukan juga dapat membuktikan bahwa keberhasilan pengasuhan yang baik adalah karena adanya konsistensi orangtua dalam mengasuh anaknya, namun ketika orangtua belum mampu untuk konsisten dalam pengasuhan anak, menjadi penyebab kurang idealnya sebuah pengasuhan.

\section{KESIMPULAN DAN SARAN}

Tingkat kehangatan orangtua dalam pengasuhan anak tergolong rendah, hal ini disebabkan karena keterbatasan waktu yang dimiliki oleh para orangtua dalam menjalin kedekatan dengan anaknya, kurangnya penghargaan dukungan dan responsif pada anak inilah yang menyebabkan kehangatan kurang terbentuk dalam pengasuhannya, hal ini dapat dilihat dari perkembangan anak yang belum matang emosi secara usianya, keterlambatan dalam menerima belajar, kurang percaya diri dan belum terlatih kemandiriannya. dari komunikasi berkualitas inilah orangtua dapat belajar untuk dapat selalu ada untuk anak meskipun waktu yang dimiliki tidak selalu bersama. Orangtua tetap dapat mengerjakan kesibukan yang dimilikinya namun orangtua juga dapat belajar untuk memaksimalkan pengasuhannnya, sehingga dengan adanya komunikasi berkualitas anak akan merasa mendapatkan perhatian dari orangtuanya. Kesibukan yang dimiliki oleh orangtua bukanlah kendala untuk menjalin kehangatan yang baik pada anak ketika orangtua mampu untuk terus konsisiten dalam melakukan komunikasi berkualitas. Hasil penelitian ini menunjukkan bahwa komunkasi berkualitas efektif dalam meningkatkan kehangatan pengasuhan.

Penelitian ini diakui masih memiliki banyak kekuarangan, oleh karena itu bagi peneliti selanjutnya yang ingin melakukan atau melanjutkan penelitian ini diharapkan menggunakan subyek yang lebih besar lagi.

\section{DAFTAR PUSTAKA}


Arikunto, Suharmi. 2002). Prosedur peneltian: suatu pendekatan praktek edisi revsis V. Jakarta: Rineka Cipta

Asfiati. 2017. Membudidayakan Quality Time Versi Konsep Pendidikan Islam yang Syarat Nilai Globalisasi dalam Mengurangi Kasus Pencuikan Anak di Indonesia. Jurnal diterbitkan

Barbara A. 2004. Overview Styles Of Parenting. Journal of perinatal Education Vol, 13 No 1, Hlm 42-44

Baumrind. 2008. Parental Authority and Its Effect On Children. Parenting and Moral Growth, Spring, 2008, The Council For Spriritual and Ethical Education. Journal

Baumrind. 1991. The Influence of Parenting Style on Adolencent Competence and Subtance use. journal of early adolence

C Drew. 2006. Ketika anak sulit diatur. Jakarta: Erlangga

Dimas, M.R. 2006. 20 Langkah Salah Mendidik Anak. Bandung: Syaamil

Fithria. Pengasuhan Dimensi Kehangatan Keluarga (Family Warmth Dimension of Bearing). Idea Nursing Journal. ISSN: 2087-2879

Hurlock. 1997. Perkembangan Anak (terjemahan). Jakarta: Erlangga
Idrus Muhammad. 2009. Metode Penelitian Ilmu Sosial Pendekatan Kuantitatif dan Kualitatif. Edisi Refisi. Jakarta: Erlangga

Indriani. 2014. EfektifitasKomunikasi Interpersonal Kepala Sekolah. Skripsi UIN Syarif Hidayatullah Jakarta

Liche, Aris, \& Bernadett. 2011. Psikologi Eksperimen. Jakarta: PT Indeks

Niken \& Theresia. 2004. Hubungan Antara Kualitas Relasi Ayah Dengan Harga Diri Remaja Putra. Jakarta: Jurnal Psikologi Vol 2 No 1

Papalia, dkk. 2005. Human Development (Perkembangan Manusia). Jakarta: Salemba Humanika

Purwanto. 1988. Komunikasi interpersonal dalam keluarga. Laporan penelitian (tidak diterbitkan). Yogyakarta : gajah mada university press

Putu \& Adijanti. 2014. Hubungan Antara Intensitas Quality Time Ibu dan Anak dengan Asertivitas Remaja. Jurnal Psikologi Udaya Vol. 1 No 3 HIm 1-11 ISSN 977-2339281-01-9

Rahmat Jalaludin. 2007. Psikologi Komunikasi. Bandung: PT Remaja Rosdakarya

Sunarti, E. 2005. Mengasuh dengan Hati Tantangan yang Menyenangkan. Jakarta: PT Alex Media Komputindo 